ist eine Aufgabe der Zuchtleitung jeder einzelnen Population. Dabei müssen die vorherrschenden Produktionsbedingungen durch entsprechende Wirtschaftlichkeitskoeffizienten und zusätzlich die populationsspezifischen genetischen Parameter der Leistungsmerkmale berücksichtigt werden. Von der Wissenschaft können hierfür lediglich Berechnungsansätze bereitgestellt werden.

\title{
L'AMÉLIORATION GÉNÉTIQUE DE LA PRODUCTION DE VIANDE, DANS LES TROUPEAUX SPÉCIALISÉS ET PAR CROISEMENTS DANS LES TROUPEAUX LAITIERS
}

\author{
F. Menissier, B. Vissac, J. Frebling. - Département de Génétique animale, C. N.R.Z., \\ 78350 Jouy en Josas (France) (1).
}

Dans les prochaines années, compte tenu de la réduction du nombre de vaches laitières en Europe, l'augmentation de la production de viande se fera par un accroissement du croisement avec des taureaux de races à viande dans les élevages laitiers et par un développement des troupeaux de vaches allaitantes à partir des femelles éliminées de la traite. Dans ce processus général d'évolution dans l'utilisation du matériel génétique où la production de viande apparaît comme un sous-produit de la sélection laitière, la situation de chaque pays varie selon ses caractéristiques agronomiques, climatiques et structurelles, les besoins de son marché et les potentialités de son matériel génétique. Les situations de production de viande seront donc nombreuses pour l'Europe.

Le développement de stratégies de croisement à partir des cheptels de femelles existants et de races paternelles ayant des aptitudes complémentaires, se justifie et s'explique :

- par la spécificité des fonctions exploitées d'une part chez la femelle laitière ou allaitante, d'autre part chez les produits destinés à la boucherie ;

- par les oppositions fréquentes entre la contribution des gènes de la mère et celle des gènes du produit pour un caractère donne ;

- et par l'importance des effets d'hétérosis.

Les stratégies de croisement envisageables se déterminent en fonction du type d'exploitation des mères et du matériel génétique disponible. Les objectifs de choix des races paternelles (ou types génétiques ou souches) vont alors dépendre des stratégies retenues ainsi que de l'utilisation des produits femelles issus de ces races paternelles (abattage comparable à celui des mâles de boucherie, abattage après un premier vêlage précoce, exploitation comme vaches allaitantes assurant ou non leur renouvellement). Dans un contexte donné, les solutions optimum à promouvoir doivent découler d'études de synthèse prenant en compte notamment les restrictions et équilibres indispensables entre les composantes maternelles et paternelles de certains caractères (aptitude au vêlage et croissance avant sevrage).

Pour réaliser de telles études de synthèse, notre connaissance du matériel génétique existant est très insuffisante en ce qui concerne les contributions additives et non additives des gènes de la mère et du produit tant sur les caractères de productivité numérique que sur ceux de productivité pondérale. Les expériences réalisées en Europe sont trop limitées dans leur durée, dans la diversité du matériel génétique employé et dans le niveau d'analyse génétique, pour répondre en temps opportun et de façon efficace aux choix qui se posent dans la plupart des pays. Ainsi, les modèles de synthèse actuellement employés ignorent souvent les différences de productivité numérique entre races ainsi que l'incidence de la musculature sur la définition des âges optimum d'abattage et sur la valeur bouchère des vaches de réforme. Incontestablement, la notion de race devrait être dépassée dans de telles expériences et analyses, compte tenu de la diversité des souches existantes dans la plupart de nos races (Charolaise, Pie-Noire, Simmental, Brune des Alpes). Une action commune (ou tout au moins concertée) à partir des populations de femelles laitières et sur la base des schémas expérimentaux proposés par Dickerson (I969) serait du plus haut intérêt en Europe.

Par ailleurs, dans la mesure où l'insémination artificielle est très développée en Europe, les schémas intégrés de sélection des mâles (noyau de femelles, contrôle individuel puis contrôle de descendance) sont très efficaces et fournissent l'information nécessaire à l'amélioration de la productivité. Ces schémas de sélection constituent des situations dans lesquelles les nouvelles techniques de reproduction (transplantation d'œufs en particulier) vont être efficacement rentabilisées même en l'état actuel de ces techniques ; un accroissement notable du progrès génétique

() Ce texte résume la plaquette en anglais des mêmes auteurs : Optimun breeding plans for beef cattle. Bull. tech. Dép. Genét. anim. (I. N. R. A., Fr.) no 21,102 p. 
est donc prévisible, en particulier pour les composantes maternelles de nombreux caractères. De plus, le progrès génétique réalisé dans ces schémas de sélection est indirectement diffusé chez les producteurs pratiquant la monte naturelle, par l'utilisation des fils de taureaux très favorablement indexés en insémination artificielle.

L'application des stratégies optimales d'utilisation du matériel génétique pour la production de viande, risque d'avoir de profondes conséquences sur les populations animales existantes : la proportion de femelles allaitantes croisées issues des élevages laitiers et, secondairement, des élevages de races rustiques, devrait s'accroitre au détriment des femelles allaitantes de races à viande spécialisées. En fait cette évolution et la mise en œuvre de tous ces systèmes d'utilisation du matériel génétique femelle pour la production de viande, restent dépendantes de la capacité du monde agricole à concevoir une organisation suffisamment large et efficace à partir des milieux de production, des opérateurs existants ou potentiels, de l'orientation la plus probable de la demande des consommateurs (quantité, qualité, prix de la viande bovine) et des contraintes temporelles qui caractérisent l'amélioration génétique des bovins.

\title{
Emploi du croisement pour la production de viande ovine
}

\section{CROSSBREEDING FOR MEAT PRODUCTION IN SHEEP}

\author{
M. BICHARD. - Pig Improvement Company Ltd., Fyfield Wick, near Abingdon, Berkshire OX13 \\ $5 N A$ (United Kingdom).
}

Crossbreeding may have three different forms : new breed synthesis, grading up, and repeated crossing between continuing purebred populations. Perhaps because sheep production has not been particularly profitable in recent years we have not seen many new breeds developed, and traditional patterns of pure and crossbreeding have continued. There has been a considerable increase in our understanding of the theory of crossbreeding since the concept of overall production or profit has been integrated into genetic theory. A crossing system may exploit profit heterosis arising from a number of different mechanisms. Nevertheless, because of the low reproductive rate of almost all existing female sheep, such systems are only of commercial interest where surplus females are available from one environment for exploitation in another. Thus the well developed stratification pattern in Britain takes the relatively unproductive but welladapted hill ewes, and by the use of specialized sire lines produces first cross ewes and 3-breed cross lambs for meat production in more favourable lowland environments. We may expect to see existing breeds and crosses evaluated more carefully in the future in order to see where designed crossbreeding systems can prove more useful, but such work will not be simple.

\section{CROSSBREEDING IN SHEEP IN RESPECT TO ECONOMIC EFFICIENCY}

\section{R. WAssmuth. - Institut für Tievzucht und Haustiergenetik Universität Giessen, Bismarckstr. 16 6300 Giessen (BRD).}

In this paper a set of factors are discussed which influence the economic efficiency of sheep in respect to crossbreeding. These factors are

a) the percentage of birth difficulties in the different crosses,

b) the differences in losses in lambs,

c) the relation between the weight of the ewe and food conversion between the optimum carcass weight and price per $\mathrm{kg}$ of the lambs carcass. This in the purebreds and crosses,

d) the management system,

$e$ ) the relation between the costs of food for maintainance in ewes, the costs of food for production in ewes and the costs of food for lambs,

f) subsidies for utilizing fallow land.

It could be shown by model calculations, that the economic efficiency is not always higher in crossbreeding than in pure breeding. Furthermore, that not always the smallest ewe even with equal number of raised lambs per year, has the best results in economic efficiency. It can be concluded that beside all the very important and necessary comparisons between performances of breeds and crosses economic efficiency can be an additional help in finding the most suitable cross combination for given environmental conditions and management systems. 